\title{
入出力のウェーブレット変換を用いた多自由度系の パラメトリックなシステム同定 \\ IDENTIFICATION OF STRUCTURAL PARAMETERS OF MDOF STRUCTURE BY WAVELET TRANSFORM
}

\author{
曾根 彰*, 山本鎮 男**, 増田 新*** \\ Akira SONE, Shizuo YAMAMOTO and Arata MASUDA
}

\begin{abstract}
The method to identify structural parameters of multi-degree of freedom structures by the wavelet transform of the input and responses is presented. For the input of a white noise, the stiffness matrices and damping matrices for two-degree-of-freedom structure, five-degree-of-freedom structure and simply supported beam modelled by finite elements are tried to be identified and it is proven that the proposed method can be used to detect the change of structural parameters with enough accuracy.
\end{abstract}

Keywords: Identification, Wavelet Transform, Structural Parameter, MDOF Structure, Mexican Hat 同定, ウェーブレット变換, 構造パラメータ, 多自由度構造物, メキシカンハット

\section{1. 粕言}

建築物，構造物は地震などの動荷重をうけて損傷劣化する。損甥 か溌生する之系の動特性 すなわち固有振動数や減衰等力変化する。 一般的には, 系の固有振動数が低下し, 減衰が増加するが, これら の变化を捉えることができれば，構造物の劣化の程度を判定するこ とができ，構造物のヘルスモニタリングが可能となる。これまで， 著者らは, ヘルスモニタリングシステムとして, 各種構造物が動的 荷重を受けて疲労して損傷する場合に，その損傷の度合をウェーブ レット変換を用いて分析するシステムを提案した”。さらにこの 手法の応用として, 強震記録のウェーブレット変換によリ履歴復元 力特性を有する建築物の累積損傷を推定する手法を示した ${ }^{2)}$ 。

構造物の動特性の同定する手法に関しては以前から多くの研究者 によって検討されてきだ), 市。これらは，モードの固有振動数，減 衰定数, 固有モード等のモーダルパラメータを同定する方法と, 直 接質量, 剛性, 減衰のような物理量（構造物パラメー夕）を同定す る方法に分けられる。さらに，同定手法は，周波数領域で行うもの 之時間領域で行うものとに大別される。このような同定手法が構造 物のヘルスモニタリングに応用されている。例えば，地震動を受け 損傷した構造物のヘルスモニタリングに関しては，時間領域て岡性 や減衰などの構造パラメー夕を同定し，それらの変化により損伤を
推定している研究があるす。ささらに モーダルパラメータからトラ 状の構造物の損稘検出を行った研究屯見られているす。最近では, ニューラルネットワークを用いて構造パラメータの変化を検出する 方法も検討されている゙。

著者らは，パラメトリックなシステム同定，すなわち構造パラメ 一夕の変化の様子を捉えるのに, 時間一周波数解析の可能なウェー ブレット解析を用いた手法を提案している。既報名では, 構造物と して 1 質点系を取り上げて, 常時微動の入力と出力のウェーブレッ 卜変換により, 構造物の動特性（固有周期と減衰）を同定する手法 を示し，その有効性を明かにした。本同定手法は, 速度応答, 加速 度応答を計測しなくても変位応答の計測のみで, 構造パラメー夕が 算出されるという特徵を持つ。これは, 系の運動方程式の両辺をウ ェーブレット変換すると, 微分項のウェーブレット変換はウェーブ レットの微分と変位との積の形になることを利用したものである。 したがって，もとの微分方程式は代数方程式として取り扱いが可能 となり，構造パラメータが最小 2 乗法を用いて同定される。これら のことは空フーリエ恋換を用いても同じ手法がとれるが, パラメー 夕が変化したとき, その変化する位置が悹フーリエの空枠と一致し ていなくてはならない。パラメータの変化位置は予めわからないの で空フーリ工変換を用いた場合に，これを試行錯誤によって探さな
* 京都工芸繊維大学工芸学部機械システム工学科 助教授・ 工博

** 京都工芸瀻維大学二芸学部機械システム工学科 教授・ 工博

*** 京都工芸繊維大学工芸学部機械システム工学科 助手
Assoc. Prof., Dept of Mechanical and System Engineering, Faculty of Engineering and Design, Kyoto Institute of Technology, Dr. Eng.

Prof., Dept. of Mechanical and System Engineering, Faculty of Engineering and Design, Kyoto Institute of Technology, Dr. Eng.

Assistant, Dept. of Mechanical and System Engineering, Faculty of Engineering and Design, Kyoto Institute of Technology 
くてはならない。したがって，本論文で提案したようにウェーブレ ット変換を用いる有意性がある。

本論文で， 2 質点系モデル，5質点系モデル，さらには橋梁を イメージした両端単純支持はりの有限要素モデルを用いて, 数值シ ミュレーションを行い，上述の同定手法の有効性を検証した。

\section{2. ウェーブレット変換による樓造パラメータの同定手法}

最初に, 構造物への入力とその出力のウェーブレット変換により 系の構造パラメー夕を同定する方法を以下に示す。なお，同定する 系として，多自由度系を考える。N自由度系の運動方程式は次式に なる。

$$
\mathbf{M} \overline{\mathbf{x}}+\mathbf{C} \dot{\mathrm{x}}+\mathbf{K x}=\mathbf{Q}
$$

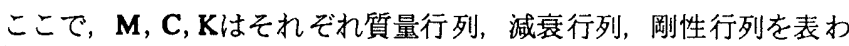
す。 $\mathbf{x}$ 亡Qは変位べクトルと入力ベクトルであ。これらの構造パ ラメータを含む特性行列の成分をウェーブレット変換によって求め ることを考える。まず，最初に関数 $\mathrm{x}(\mathrm{t})$ の連続ウェーブレット変換 は次式で与えられる”。

$$
(w x)(a, b)=\frac{1}{\sqrt{a}} \int_{-\infty}^{\infty} x(t) \psi\left(\overline{\left(\frac{t-b}{a}\right)} d t\right.
$$

$\mathrm{a} \neq 0, \mathrm{~b}$ は共に実数であり，それぞれスケール変換とシ

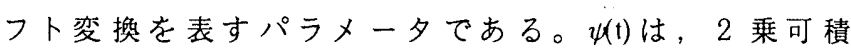
分関数でアナライジングウェーブレットであり，また $\bar{\psi}(\mathrm{t})$ は $\psi(\mathrm{t})$ の複素共役を表す。一方, ウェーブレットがコンパクト サポートであるという性質より，ウェーブレット変換に部分積分を 適用する亡応答の $\mathrm{n}$ 階微分 $\mathrm{x}^{(n)}$ のウェーブレット変換は次のように 表される ${ }^{10)}$ 。

$$
\left.\left(w^{(n)}\right)(a, b)=(-1)^{n} \frac{1}{a{ }^{n} \sqrt{a}} \int_{-\infty}^{\infty} \overline{\psi^{(n)}\left(\frac{t-b}{a}\right)}\right) x(t) d t
$$

$\mathrm{a}, \mathrm{b}$ を $\mathrm{a}=2^{\mathrm{j}}, \mathrm{b}=2^{\mathrm{i}} \mathrm{k}$ と離散化したとき, 式（1）のウェーブレット変換 のm行目の成分は, 内積表示により次式になる。

$$
\begin{aligned}
& \sum_{n} m_{m n}\left\langle\psi_{j, k}^{(2)}, x_{n}(t)\right\rangle+\sum_{n} c_{m n}\left\langle\psi_{j, k}^{(1)}, x_{n}(t)\right\rangle \\
& +\sum_{n} k_{m n}\left\langle\psi_{j, k}, x_{n}(t)\right\rangle=\left\langle\psi_{j, k}, Q_{m}(t)\right\rangle
\end{aligned}
$$

ただし，

$$
\psi^{(\mathrm{n})} \mathrm{j,k}=2^{\mathrm{nj}} 2^{\mathrm{i} 2} \psi^{(\mathrm{n})}\left(2^{\mathrm{j}} \mathrm{t}-\mathrm{k}\right)
$$

ここで， $\psi_{\mathrm{j}, \mathrm{k}}^{(\mathrm{n})}$ はウェーブレット $\psi_{\mathrm{j}, \mathrm{k}}$ のn 階微分を表わす。 $\mathrm{Q}_{\mathrm{m}}$ は入力の $\mathrm{m}$ 番目の成分を表わし， $\mathrm{m}_{\mathrm{mn}}, \mathrm{c}_{\mathrm{mn}}, \mathrm{k}_{\mathrm{mn}}$ は同定するパラメー夕を表わす。 式 (4) からわかるように, 微分項のウェーブレット変換は, ウェ 一ブレットの微分と変位との内積として表わされる。したがって, 速度応答, 加速度応答を計測しなくても变位応答の計測のみて，構 造パラメー夕の諸量の関連が表わされる。これらの係数の推定値を $\tilde{\mathrm{m}}_{\mathrm{mn}}, \widetilde{\mathrm{c}}_{\mathrm{m} n}, \widetilde{\mathrm{k}}_{\mathrm{mn}}$ とし，式（4）を式誤差e(t)を含む式で表わすと次のよ
うになる ${ }^{8), 10 \%}$

$$
\begin{aligned}
& \sum_{n} \tilde{m}_{m n}\left\langle\psi_{j, k}^{(2)}, x_{n}(t)\right\rangle+\sum_{n} \tilde{c}_{m n}\left\langle\psi_{j, k}^{(1)}, x_{n}(t)\right\rangle \\
& +\sum_{n} \tilde{k}_{m n}\left\langle\psi_{j, k}, x_{n}(t)\right\rangle-\left\langle\psi_{j, k}, Q_{m}(t)\right\rangle=\left\langle\psi_{j, k}, e(t)\right\rangle
\end{aligned}
$$

本研究では, 式 (6) の右辺の式誤差 $\mathrm{e}(\mathrm{t})$ のウェーブレット変換の 2 乗を最小とするように式 (6) の構造パラメー夕 $\left(\widetilde{\mathrm{m}}_{\mathrm{mn}}, \widetilde{\mathrm{c}}_{\mathrm{mn}}, \widetilde{\mathrm{k}}_{\mathrm{mn}}\right)$ を同定する。具体的には，構造パラメータの同定の評価規範として は，次式の離散化した值を用いた。

$$
\mathrm{J}=\sum_{\mathrm{i}} \sum_{\mathrm{k}} \mid\left\langle_{\mathrm{j}, \mathrm{k}}, \mathrm{e}(\mathrm{t})\right\rangle^{2}
$$

本研究では, アナライジングウェーブレットとして, ガウス関数を 2 回微分したラプラシアンガウシアン関数 (Mexican hat) を用いる。 すなわち

$$
\psi(t)=\left(1-t^{2}\right) \exp \left(-\frac{t^{2}}{2}\right)
$$

このアナライジングウェーブレット $(\mathrm{t})$ は，時間空間，周波数空間 共に局在し，解析的に微分可能である。図 1 にこの波形を示す。

\section{3.シミュレーション結果}

本研究では，2 質点系モデル，5質点系モデル，さらには雨端単 純支持はりの有限要素モテルを用いて，数值シミュレーションを行 い，本手法の検証を行った。以下にその結果を示す。

(1) 2 質点系の場合

ここでは，図2の2質点系モデルのシミュレーション結果を示す。 入力 $q(t)$ は上部質量 $\mathrm{m}_{1}$ に作用するものとする。ここで，入力 $q(t) ，$ 応 答 $\mathrm{x}_{1}(\mathrm{t})$ と $\mathrm{x}_{2}(\mathrm{t})$ を観測する。まず，図 2 の入力 $\mathrm{q}(\mathrm{t})$ をサンプリング時間

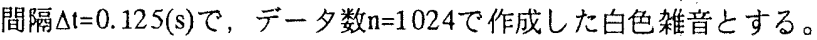
これを入力として変位応答 $x_{1}(t), x_{2}(t)$ をRunge-Kinta-Gill法により数值 積分して求めた。系のパラメー夕の值として, $\mathrm{m}_{1}=\mathrm{m}_{2}=1.0 \mathrm{~kg}, \mathrm{k}_{1}=\mathrm{k}_{2}$ $=9.87 \mathrm{~N} / \mathrm{m}, \mathrm{c}_{1}=\mathrm{c}_{2}=0.314 \mathrm{Ns} / \mathrm{m}$ を与えた。ただし，系の劣化を考虑して 時刻 $\mathrm{t}=64 \mathrm{~s}$ で㓮性 $\mathrm{k}_{2}$ と減衰係数 $\mathrm{c}_{2}$ が 10\%低下すると仮定する。

図 3 に, 入力 $q(t)$ と変位応答 $x_{2}(t)$ の例を示す。この入力 $q(t)$ と応答 $x_{1}(t), x_{2}(t)$ を観測值として，これよりパラメータの值を式（7）の規 範を最小にするように同定した。表1にその同定結果を示す。ただ

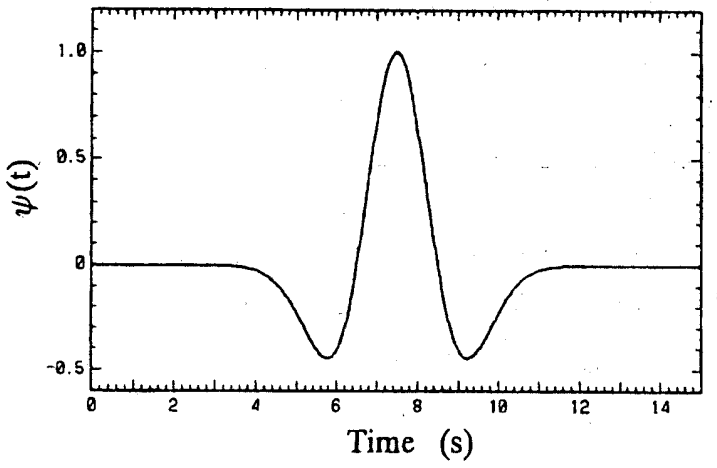

図1 Mexican hat 


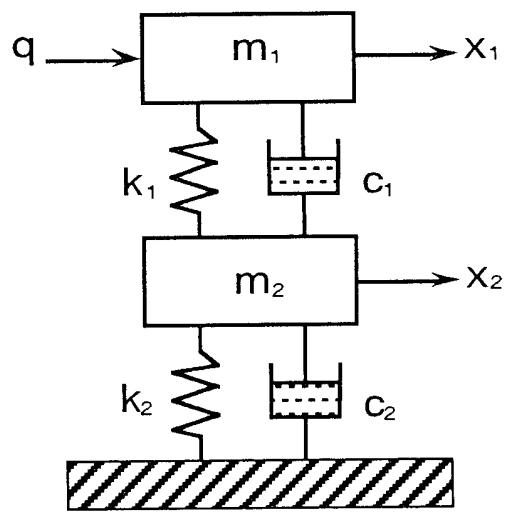

図2 質点系モデル

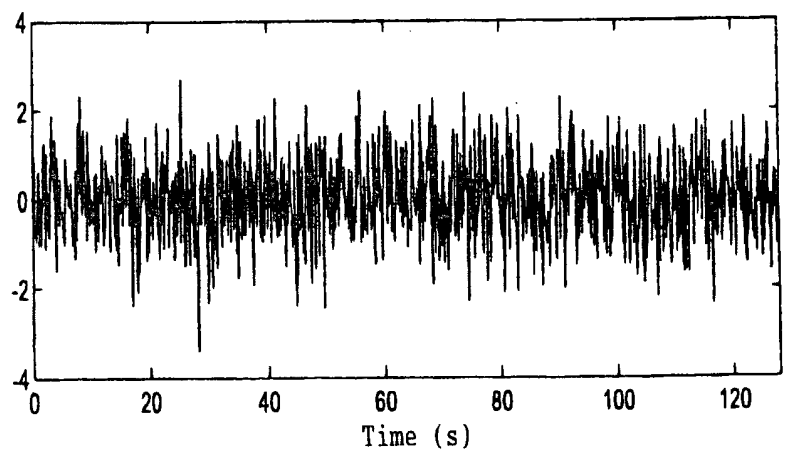

(a) $q(t)$

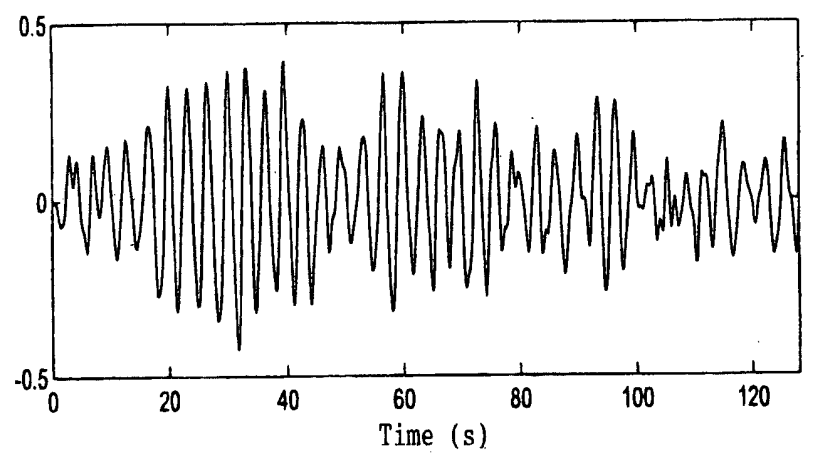

(b) $\mathrm{x}_{2}(\mathrm{t})$

図 3 入力亡变位応答波形例

表 1 同定結果（2質点系モデル、損傷有）

\begin{tabular}{|c|c|c|}
\hline Parameter & Exact Value & Identified Value \\
\hline $\mathrm{k}_{1}(0-64 \mathrm{~s})$ & 9.87 & 9.89 \\
\hline $\mathrm{k}_{2}(0-64 \mathrm{~s})$ & 9.87 & 9.88 \\
\hline $\mathrm{c}_{1}(0-64 \mathrm{~s})$ & 0.314 & 0.314 \\
\hline $\mathrm{c}_{2}(0-64 \mathrm{~s})$ & 0.314 & 0.314 \\
\hline \hline $\mathrm{k}_{1}(64-128 \mathrm{~s})$ & 9.87 & 9.87 \\
\hline $\mathrm{k}_{2}(64-128 \mathrm{~s})$ & 8.88 & 8.89 \\
\hline $\mathrm{c}_{1}(64-128 \mathrm{~s})$ & 0.314 & 0.314 \\
\hline $\mathrm{c}_{2}(64-128 \mathrm{~s})$ & 0.283 & 0.289 \\
\hline
\end{tabular}

し，これらの数値計算において, スケールパラメータ $\mathrm{j}$ は各固有周 期を含むように設定し，高い周波数はカットした。表で，上部が 0

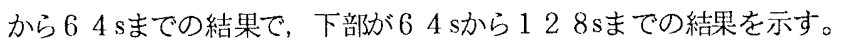

まず，剛性を見ると，推定値の誤差が最大約 $0.2 \%$ 以下であり，かな り良い精度で同定されていることがわかる。一方, 減衰係数につい ては，減衰係数は変化した場合で最大約 $2.2 \%$ 同定誤差が見られ る.これらの結果より, ウェーブレット変換を用いたシステムパラ メー夕の同定が有効であることがわかった。さらに, システムパラ メー夕が变化しても精度よい同定結果が得られることが検証された。

次に, 1 次固有周期が 0.2 秒 1.0 秒程度の範囲, 減衰定数が $1 \%$ $5 \%$ 程度の範囲から5ケースを選び，標準的な 2 屏建物への適用性を 検討した。その結果を表 2 表 6 に示す。入力 $\mathrm{q}(\mathrm{t})$ をサンプリング時 間間隔 $\Delta \mathrm{t}=0.01(\mathrm{~s})$ で，デー夕数 $n=1024$ で作成した白色雑音とする。 さらに, $\mathrm{m}_{1}=\mathrm{m}_{2}=1.0 \mathrm{~kg}$ であり、剛性亡減衰係数は変化させていない。 これらの表から，魝性の推定誤差が最大で約 $1.4 \%$ 以下，減衰係数の 推定誤差が最大で約 $4.2 \%$ 以下であることがわかり，本手法の適用性 が確認された。しかし, 誤差は 1 次固有周期とサンプリング周期が 近いほど大きくなっているため，同定精度を上げるためには適切な

表2 同定結果（2質点系モデル、損傷無、その 1 )

\begin{tabular}{|c|c|c|}
\hline Parameter & Exact Value & Identified Value \\
\hline $\mathrm{k}_{1}$ & 2500 & 2520 \\
\hline $\mathrm{k}_{2}$ & 2500 & 2534 \\
\hline $\mathrm{c}_{1}$ & 1.62 & 1.65 \\
\hline $\mathrm{c}_{2}$ & 1.62 & 1.64 \\
\hline
\end{tabular}

表 3 同定結果（2 質点系モデル、損傷無、その 2 )

\begin{tabular}{|c|c|c|}
\hline Parameter & Exact Value & Identified Value \\
\hline$k_{1}$ & 660 & 655 \\
\hline$k_{2}$ & 660 & 651 \\
\hline$c_{1}$ & 1.66 & 1.73 \\
\hline$c_{2}$ & 1.66 & 1.70 \\
\hline
\end{tabular}

表4 同定結果（2質点系モデル、損傷算、その 3 )

\begin{tabular}{|c|c|c|}
\hline Parameter & Exact Value & Identified Value \\
\hline$k_{1}$ & 280 & 281 \\
\hline$k_{2}$ & 280 & 281 \\
\hline$c_{1}$ & 1.62 & 1.62 \\
\hline$c_{2}$ & 1.62 & 1.62 \\
\hline
\end{tabular}

表 5 同定結果 (2 質点系モデル、損傷無、その4)

\begin{tabular}{|c|c|c|}
\hline Parameter & Exact Value & Identified Value \\
\hline$k_{1}$ & 160 & 161 \\
\hline$k_{2}$ & 160 & 161 \\
\hline$c_{1}$ & 1.64 & 1.65 \\
\hline$c_{2}$ & 1.64 & 1.65 \\
\hline
\end{tabular}

表6 同定結果 (2 質点系モデル、損傷哭、その 5 )

\begin{tabular}{|c|c|c|}
\hline Parameter & Exact Value & Identified Value \\
\hline $\mathrm{k}_{1}$ & 100 & 100 \\
\hline $\mathrm{k}_{2}$ & 100 & 100 \\
\hline $\mathrm{c}_{1}$ & 1.62 & 1.62 \\
\hline $\mathrm{c}_{2}$ & 1.62 & 1.61 \\
\hline
\end{tabular}




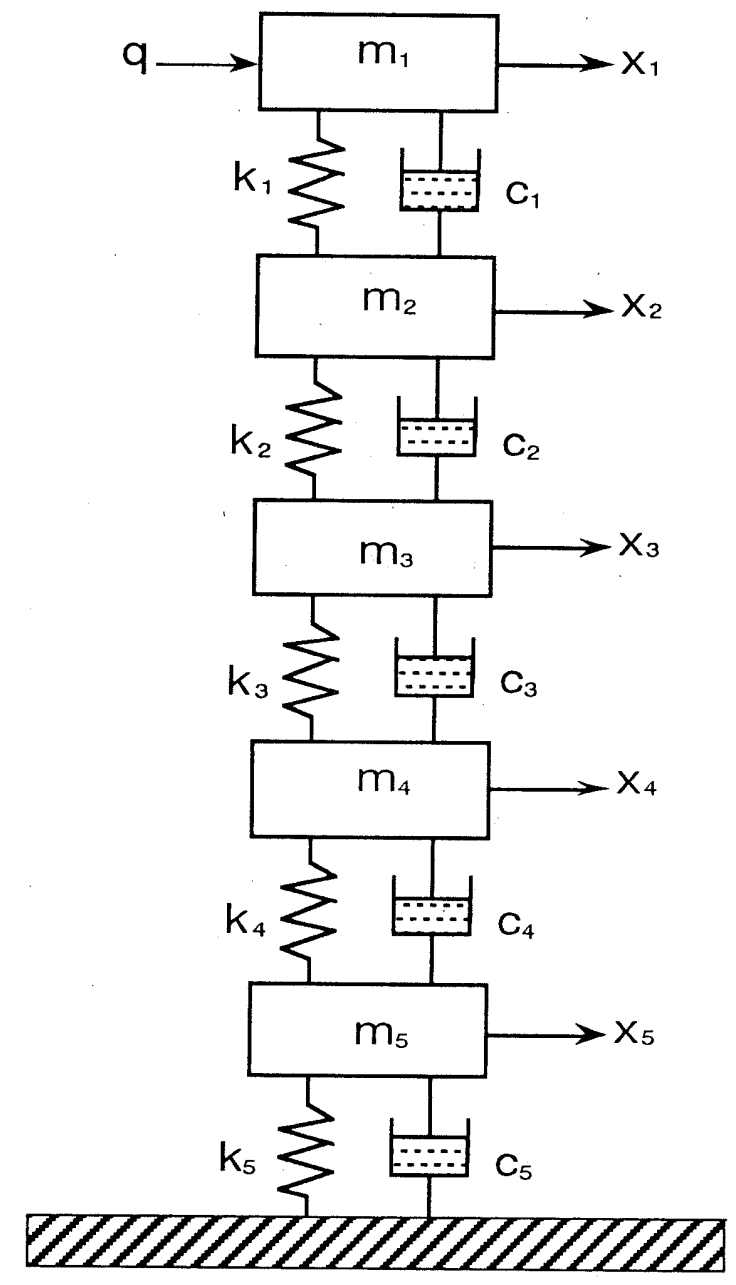

図45質点系モデル

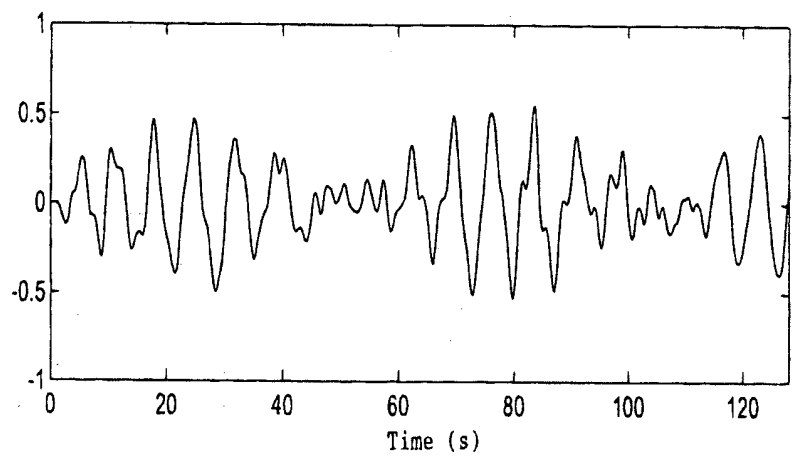

図 5 変位応答波形例

サンプリング周期が必要である。

(2.) 5 質点系の場合

ここでは，図4の5質点系モデルのシミュレーション結果を示す。 このモデルでも，入力 $\mathrm{q}(\mathrm{t})$ は上部質量 $\mathrm{m}_{1}$ に作用するものとする。こ こで，入力 $q(t)$, 応答 $x_{1}(t), x_{2}(t), x_{3}(t), x_{4}(t), x_{5}(t)$ を観測する。まず, 入力 $\mathrm{q}(\mathrm{t})$ は上記と同様の白色雑音で，サンプリング時間間隔 $\Delta \mathrm{t}=0.125(\mathrm{~s})$, データ数 $\mathrm{n}=1024$ である。これを入力として各变位応 答は数值皘分して求めた。系のパラメー夕の值として, $\mathrm{m}_{1}=\mathrm{m}_{2}$ $=\mathrm{m}_{3}=\mathrm{m}_{4}=\mathrm{m}_{5}=1.0 \mathrm{~kg}, \mathrm{k}_{1}=\mathrm{k}_{2}=\mathrm{k}_{3}=\mathrm{k}_{4}=\mathrm{k}_{5}=9.87 \mathrm{Nm}, \mathrm{c}_{1}=\mathrm{c}_{2}=\mathrm{c}_{3}=\mathrm{c}_{4}=\mathrm{c}_{5}=0.314 \mathrm{Ns} / \mathrm{m}$ を与えた。ただし，系の劣化を考慮して時刻 $\mathrm{t}=64 \mathrm{~s}^{\mathrm{s}} \mathrm{K}_{3}$ が10\%減少し，
表 7 同定結果（5 質点系、損笠有）

\begin{tabular}{|c|c|c|}
\hline Parameter & Exact Value & Identified Value \\
\hline$k_{1}(0-64 s)$ & 9.87 & 9.87 \\
\hline$k_{2}(0-64 s)$ & 9.87 & 9.87 \\
\hline$\left.k_{3} 0-64 s\right)$ & 9.87 & 9.88 \\
\hline$k_{4}(0-64 s)$ & 9.87 & 9.86 \\
\hline$k_{5}(0-64 s)$ & 9.87 & 9.87 \\
\hline$c_{1}(0-64 s)$ & 0.314 & 0.314 \\
\hline$c_{2}(0-64 s)$ & 0.314 & 0.314 \\
\hline$c_{3}(0-64 s)$ & 0.314 & 0.314 \\
\hline$c_{4}(0-64 s)$ & 0.314 & 0.316 \\
\hline$c_{5}(0-64 s)$ & 0.314 & 0.314 \\
\hline \hline$k_{1}(64-128 s)$ & 9.87 & 9.87 \\
\hline$k_{2}(64-128 s)$ & 9.87 & 9.87 \\
\hline$k_{3}(64-128 s)$ & 8.88 & 8.89 \\
\hline$k_{4}(64-128 s)$ & 9.87 & 9.91 \\
\hline$k_{5}(64-128 s)$ & 9.87 & 9.87 \\
\hline$c_{1}(64-128 s)$ & 0.314 & 0.316 \\
\hline$c_{2}(64-128 s)$ & 0.314 & 0.324 \\
\hline$c_{3}(64-128 s)$ & 0.345 & 0.314 \\
\hline$c_{4}(64-128 s)$ & 0.314 & \\
\hline$c_{s}(64-128 s)$ & 0.314 & 0.319 \\
\hline & & \\
\hline & & 9.87 \\
\hline
\end{tabular}

$\mathrm{c}_{3}$ が10\%増加すると仮定した。

図 5 に，变位応答 $\mathrm{x}_{3}(1)$ の例を示す。入力と応答を観測値として， これらよりパラメータの值を式（7）の規範を最小にするように同

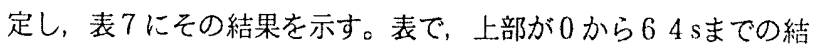
果で，下部が $64 \mathrm{~s} ら 128 \mathrm{~s}$ での結果を示す。まず，剛性を見 る亡, 推定值の誤差が最大約 $0.4 \%$ 以下であり，かなり良い精度で同 定されていることがわかる。一方, 減衰係数については, 減衰係数 が変化した場合で最大約 $5.6 \%$ 同定誤差が見られる.これらの結 果より, 若下堿衰係数の同定精度が悪いが，系の自由度が大きくな ってもウェーブレット変換を用いたシステムパラメータの同定が有 効であることがわかった。

次に，実際の建物に対する適用性をみるために，第 1 層から上層 に向かって岡性が低下するケースを2 例選び検討し，その結果を表 8 と表 9 に示す。入力 $q(1)$ は白色雑音で，サンプリング時間間隔 $\Delta \mathrm{t}=0.125(\mathrm{~s})$, デー夕数 $\mathrm{n}=1024$ である。さらに, $\mathrm{m}_{1}=\mathrm{m}_{2}=\mathrm{m}_{3}=\mathrm{m}_{4}=\mathrm{m}_{5}=$ $1.0 \mathrm{~kg}$ であり、凮性と減衰係数は変化させていない。これらの表か ら，剛性の推定誤差が最大で約 $5.8 \%$ 以，減衰係数の推定誤差が最 大で約6.4\%以下であることがわかり，本手法の適用性が確認された。

(3) 両端単純支持はりの場合

以下では，両端単純支持はりモデルのシミュレーション結果を示 す。まず，はりは図6に示すように5 分割の有限要素モデルを用い る。ここで, 各要素の㴊性行列は式 (9) に示す曲げはりの風性行

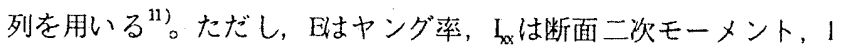
は要素の長さである。 $\mathrm{E}=2.1 \times 10^{11} \mathrm{~N} / \mathrm{m}^{2}, 1=5 \mathrm{~m}$ ，さらにはりの断面積 $\mathrm{A}=0.25 \mathrm{~m}^{2}$, 密度 $\rho=7860 \mathrm{~kg} / \mathrm{m}^{3}$ 亡設定する。なお, はりは正方形断面 とする。また，簡単のため質量行列は集中質量行列を用いる。

一方, 図6に示す入力 $\mathrm{q}(1)$ をンプリング時間間隔 $\Delta t=2^{-10}(\mathrm{~s})$ て, 
表 8 同定結果（5 質点系、損稘無、その 1 )

\begin{tabular}{|c|c|c|}
\hline Parameter & Exact Value & Identified Value \\
\hline $\mathrm{k}_{1}$ & 8.80 & 8.44 \\
\hline $\mathrm{k}_{2}$ & 9.10 & 8.99 \\
\hline $\mathrm{k}_{3}$ & 9.40 & 9.02 \\
\hline $\mathrm{k}_{4}$ & 9.70 & 9.53 \\
\hline $\mathrm{k}_{5}$ & 10.0 & 10.0 \\
\hline $\mathrm{c}_{1}$ & 0.314 & 0.326 \\
\hline $\mathrm{c}_{2}$ & 0.314 & 0.334 \\
\hline $\mathrm{c}_{3}$ & 0.314 & 0.331 \\
\hline $\mathrm{c}_{4}$ & 0.314 & 0.307 \\
\hline $\mathrm{c}_{5}$ & 0.314 & 0.306 \\
\hline
\end{tabular}

表 9 同定結果（5質点系、損傷無、その 2 )

\begin{tabular}{|c|c|c|}
\hline Parameter & Exact Value & Identified Value \\
\hline$k_{1}$ & 8.00 & 8.46 \\
\hline$k_{2}$ & 8.50 & 8.83 \\
\hline$k_{3}$ & 9.00 & 9.25 \\
\hline$k_{4}$ & 9.50 & 9.73 \\
\hline$k_{5}$ & 10.0 & 10.0 \\
\hline$c_{1}$ & 0.314 & 0.340 \\
\hline$c_{2}$ & 0.314 & 0.347 \\
\hline$c_{3}$ & 0.314 & 0.337 \\
\hline$c_{4}$ & 0.314 & 0.304 \\
\hline$c_{5}$ & 0.314 & 0.304 \\
\hline
\end{tabular}

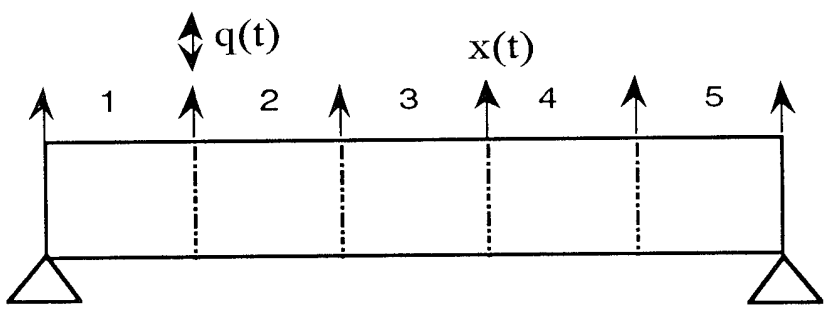

図6 両端単純支持はりモデル

$$
k=\left[\begin{array}{cccc}
\frac{12 \mathrm{EI}_{x x}}{1^{3}} & & \text { SYM. } \\
\frac{6 \mathrm{EI}_{x x}}{1^{2}} & \frac{4 \mathrm{EI}_{x x}}{1} & & \\
-\frac{12 \mathrm{EI}_{w x}}{1^{3}} & -\frac{6 \mathrm{EI}_{w x}}{1^{2}} & \frac{12 \mathrm{EI}_{w x}}{1^{3}} & \\
\frac{6 \mathrm{EI}_{\mathrm{xx}}}{1^{2}} & \frac{2 \mathrm{EI}_{\mathrm{xx}}}{1} & -\frac{6 \mathrm{EI}_{\mathrm{xx}}}{1^{2}} & \frac{4 \mathrm{EI} x}{1}
\end{array}\right]
$$

デー夕数 $n=4096$ で作成した白色雑音とする。これを入力として系の 応答を数值積分して求めた。ただし, 時間 $\mathrm{t}=2 \mathrm{~s}$ で要素 4 （斜線部） の断面 2 次モーメント $\mathrm{I}_{\mathrm{xx}}$ が10\% 低下すると仮定する。なお，このモ デルでは，減衰は零としている。

図 7 に, 入力 $q(t)$ と, 要素 3 之要素 4 の間の接点の変位応答 $\mathrm{x}(\mathrm{t})$ の

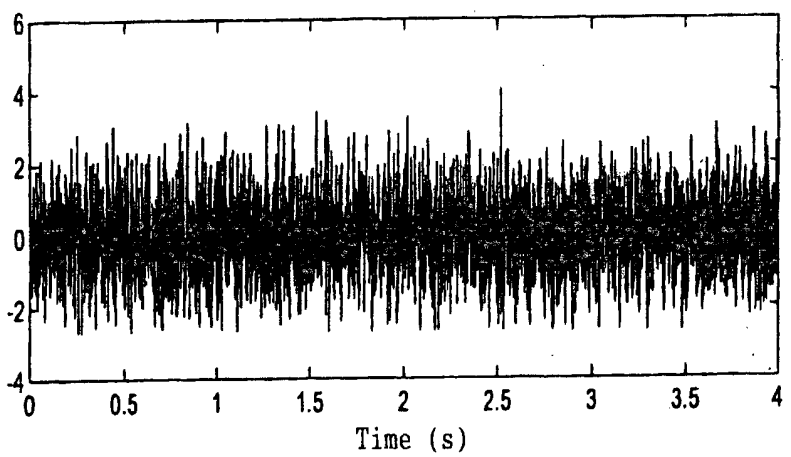

(a) $q(t)$

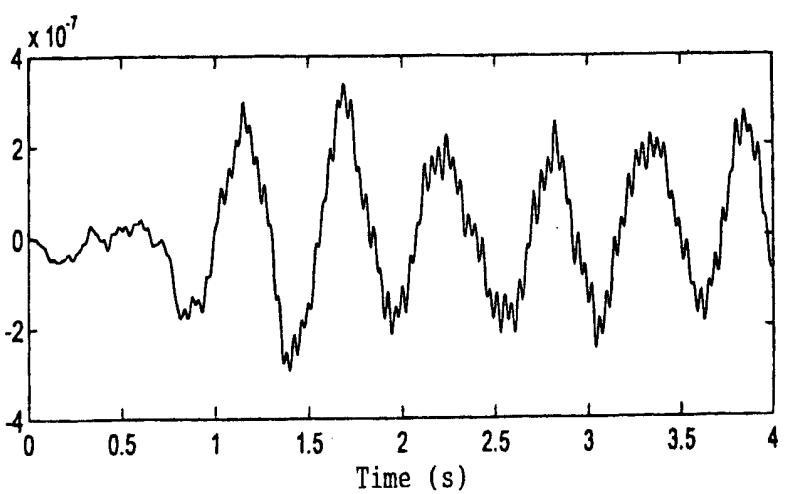

(b) $x(t)$

図 7 人力 $q(t)$ と变位応答 $x(t)$ の波形例

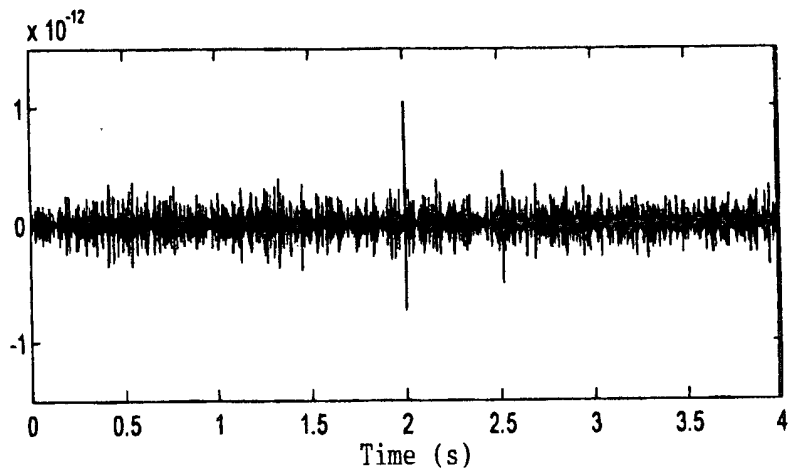

図 8 変位応答 $x(t)$ のゥーブレット展開係数

表 $10 \quad \mathrm{I}_{\mathrm{xx}}$ の同定結果 $(1=5 \mathrm{~m})$

\begin{tabular}{|c|c|c|c|}
\hline Time & Exact Value & Identified Value & Error $(\%)$ \\
\hline $\mathrm{t}=0-2 \mathrm{~s}$ & $5.208 \times 10^{-3}\left(\mathrm{~m}^{4}\right)$ & $5.207 \times 10^{-3}\left(\mathrm{~m}^{4}\right)$ & 0.04 \\
\hline $\mathrm{t}=2-4 \mathrm{~s}$ & $4.688 \times 10^{-3}\left(\mathrm{~m}^{4}\right)$ & $4.674 \times 10^{-3}\left(\mathrm{~m}^{4}\right)$ & 0.28 \\
\hline
\end{tabular}

表 $11 \mathrm{I}_{\mathrm{xx}}$ の同定結果 $(1=1.2 \mathrm{~m}, 0.6 \mathrm{~m})$

\begin{tabular}{|l|l|c|c|}
\hline 1 & Exact Value & Identified Value & Error $(\%)$ \\
\hline $1.2(\mathrm{~m})$ & $5.208 \times 10^{-3}\left(\mathrm{~m}^{4}\right)$ & $5.146 \times 10^{-3}\left(\mathrm{~m}^{4}\right)$ & 1.20 \\
\hline $0.6(\mathrm{~m})$ & $5.208 \times 10^{-3}\left(\mathrm{~m}^{4}\right)$ & $5.169 \times 10^{-3}\left(\mathrm{~m}^{4}\right)$ & 0.75 \\
\hline
\end{tabular}

例を示す。また，剛性の不連続性を調べるために, Daubechiesのウ ェーブレットを用いてこの応答 $\mathrm{x}(\mathrm{t})$ をウェーブレット変換して, 展 開係数を求めたものを図 8 に示す。この図より, 明かに $\mathrm{t}=2 \mathrm{~s}$ で不連 続を示すパルス状の波形が現われ，剛性の不連続点が検出された。

次に，入力 $q(t)$ と各接点(1)から(6)の変位応答を観测值として, 質 量行列亡剛性行列の要素の值を同定した。この值によって, はりの 
断面 2 次モーメント $\mathrm{I}_{\mathrm{xx}}$ を求めた。 $\mathrm{t}=0-2 \mathrm{~s}$ と $\mathrm{t}=2-4 \mathrm{~s}$ における $\mathrm{I}_{\mathrm{xx}}$ の設定 值とウェーブレット変換によって同定した值，およびその誤差を表 10 に示す。 なお，断面2 次モーメントの同定值は，同定した剛性 行列の要素の平均值から算出した。 $\mathrm{t}=0-2 \mathrm{~s}$ と $\mathrm{t}=2-4 \mathrm{~s}$ における断面 2 次モーメントの設定値と同定値の誤差は，それぞれ0.04\%と0.28\% でありこれより本手法の有効性が検証された。

さらに，建築の梁スパンに対する適用性をみるために， $1=1.2 \mathrm{~m}$, $0.6 \mathrm{~m}$ の 2 ケースを検討し, その結果を表 11 に示す。この表の結果 より, 推定誤差が小さく得られ, 本手法の適用性が明かとなった。

\section{4. 結言}

本論文では，入力信号と応答信号のウェーブレット変換 を用いて系の構造パラメー夕を同定した。その結果, Mexican hat のウェーブレットによって良好に推定できることがわかった。さら に，剛性や減衰低下をも同定可能であることもわかった。したがっ て, 本手法を構造物のヘルスモニタリングに適用することが可能て ある。最後に, ウェーブレット変換はフーリエ変換に比べて周波 数分解能が悪いという欠点がある。しかしながら，同定精度は，テ 一タのサンプリング時間に依存するので，ウェーブレット变換の欠 点を克服するためには適切なサンプリング時間を設定する必要があ る。この点については今後の課題としたい。 参考文献

1)曾根彰ほか 4 名：ウェーブレット変換を用いた機械・構造物のヘルスモ二 タリングシステム（正規直交ウェーブレットの生成と断続的異常信号の検出）， 日本機栈学会論文集 C 編，第61巻，第586号，pp.2340～2346，1995年6月． 2)曾根彰ほか 4 名：強震記録のウェーブレット解析による履歴復元力特性を 有与る建築物の累皘損傷の推定，日本建築学会構浩采論文集，第476号， pp. 67 74， 1995年10月.
3) Beck J. L. and Jennings P. C : Structural Identification using Linear Models and Ear thquake Engineering Records, Int. J. Ear thquake Engrg. and Struct. Dynamics, Vol. 8, No.2, pp.145 160, 1980.

4) Shinozuka M. Yun C B. and Imai H: Identification of Linear Structural Dynamic System, J. of Engrg. Mech Div. , ASCE, Vol.108, No.6, pp. 1371 1390, 1982.

5) Agbabian M.S, et al. : A System Identification Approach to the Detection of Sructur al Changes, J. of Engimering Mechanics ASCE, Vol.117, No.2, pp.370 $390,1990$.

6) Liu P. L. : Identification and Damage Detection of Trusses uing Modal Data, J. of Structural Engineering, ASCE, Vol.121, No.4, pp.599 608, 1995.

7)Masri. R., et al. : Neural Network Approach to Detection of Changes in Structural Parameters, J. of Engineering Mechanics ASCE, Vol.122, No.4, pp.370 390, 1996.

8)曾根彰ほか 3 名 : 常時微動と強震記録のウェーブレット解析による椿造物 の動特性推定とその変化の推定，日本建築学会構造系論文集，第490号， pp.65〜 72, 1996年12月.

9) Daubechies 1.: Ten Lectures on Wavelets, CBMS-NSFSeries in Applied Mathematics, SIAM Publ., 1992.

10)田原鉄也，新誠一，北森俅行：ウェーブレット変換に基づく伝達関数の係 数推定，計測自動制御学会第22回制御理諭シンポジウム諭文集，pp.231〜234, 1993年5月

11)ピルキー W. D, 岡田㓌二：機械振動とマトリクス解析法, コロナ社, 1989年7月. 